\title{
FISH CANNING INDUSTRY AND THE RHYTHM OF SOCIAL LIFE IN THE NORTHEASTERN ADRIATIC
}

Original scientific paper Submitted: 8. 1. 2020 Accepted: 9. 3. 2020

DOI: $10.15176 /$ vol57no102

UDK 338.45:664.951.6](497.572)

316.344.26(497.572)

$321.74(497.1)$

\section{TANJA PETROVIĆ \\ ZRC SAZU, Institute of Culture and Memory Studies, Ljubljana}

The article discusses the social world formed around canneries in small coastal and insular towns in the northeastern Adriatic. Although associated with hard, unpleasant labor and demanding work conditions, the fish canning industry, particularly in the period of late socialism, offered a framework in which a meaningful social life was organized and lived. In this way, the local impact of canneries reached much beyond providing financial means to its employees. To understand the social meaning of fish canning in the Yugoslav Adriatic, the article focuses on the relationship between the now largely vanished local fish canning industry and tourism that is increasingly becoming the dominant (and the only) source of income for local communities. Lefebvre's concept of rhythmanalysis proves to be a productive lens to view the complex and often ambiguous relationship between the two industries, and to narrate the history of fish canning through the senses - what was seen, heard, smelled, felt. These intense, embodied, sensorial memories caution us that the dominant claims and narratives which interpret the replacement of industry with tourism (and other tertiary sector activities) as a necessary, inevitable and desirable developmental step should not be taken for granted.

Keywords: fish canning, labor, social rhythm, odor, industrial heritage

\section{INTRODUCTION}

The village of Banjole is situated several kilometers southeast from the Istrian city of Pula. In the early spring of 2018, when I visited it, it was a tranquil small coastal place preparing for the coming tourist season. Restaurant owners cleaned and repainted their outside seating, and fishermen, for who Banjole had been famed in the past, cleaned and 
painted their small boats. A large building painted in bright colors dominates the village, disrupting the coastline and making a significant portion of land inaccessible to locals, tourists and random visitors outside the season. It is the recently built hotel Del Mar. The hotel was built where the building of the fish canning factory used to stand.

There are no material remnants of the fish canning history in this small coastal place, except for a sculpture of a half-open fish can. The inside of the can-sculpture features a blue plaque with an informative inscription in four languages (Croatian, Italian, German and English). The English inscription reads:

This sculpture tells the story of the sardine factory "Angelo Parodi," "Učka," "Istra," "Mirna" from early 1927 to 1990. On her place today rises the aparthotel "Del Mar."

Only the Croatian text on the sculpture is longer and reads:

From its very beginning fabrika ${ }^{2}$ had a significant economic and social importance for the inhabitants of Banjole and of other neighboring settlements (Premantura, Pomer, Medulin, Ližnjan, Vinkuran, Šišan, and even Pula). In the 1970s, when its development reached its peak, fabrika employed around 300 female workers in production and 150 fishermen and other support staff. It that period, it built a fleet consisting of ten fishing boats. There was a cinema hall, a dancing hall and a medical practice regularly operating in the fabrika. The then director Mario Benvenuti importantly contributed to the development of the fabrika. Among other things, he organized a music school for various instruments, attended by some 15 factory workers. Because of it, one could often hear the accordion playing in Banjole.

It was not easy to recall the sound of the accordion in this place void of local sounds and life on that spring day. Everything around suggested that the sounds are yet to come with the tourists; that the life in Banjole is closely connected, and deeply dependent on their presence, and that the rhythm of life here runs cyclically, with tourist seasons and out-of-season time taking each other's place.

${ }^{1}$ This article is a result of the research program "Historical interpretations of the 20th century" (P60347) financed by the Slovenian Research Agency, and the following research projects: the bilateral research project "Consequences of Deindustrialization of the Eastern Adriatic Coast: (Dis)Entangling People, Landscape and the Sea," financed by ARRS (Slovenia) and DAAD (Germany) and was realized in 2018 and 2019 together with the Leibniz Institute of East and Southeast European Studies in Regensburg; basic research project "Music and politics in the post-Yugoslav space: Toward a new paradigm of politics of music in the 21st century" (J6-9365), financed by the Slovenian Research Agency (ARRS, 2018-2021).

${ }^{2}$ Fabrika is an Italian word used for fish canning factories in Croatia. 

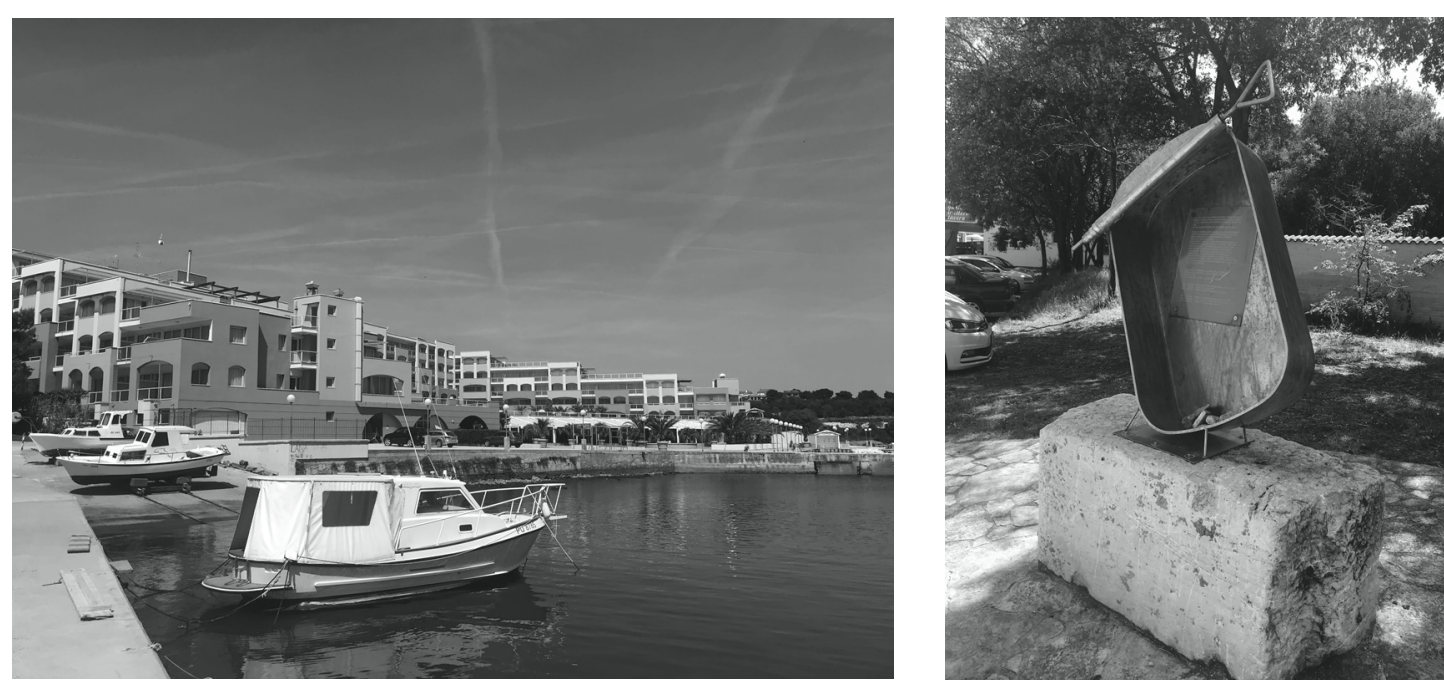

Photos 1 and 2. Banjole with the Del Mar hotel and the can-shaped monument to the vanished canning industry. Photos by Tanja Petrović

This article discusses the relationship between the now largely vanished local fish canning industry and tourism in coastal and insular towns of the northeastern Adriatic. The multilingual inscription placed in the can-sculpture, signed by the inhabitants of Banjole (Meštani Banjola), reveals some tensions relevant for this discussion. The most important one is textually embodied in the relationship between the seemingly disinterested, neutral paragraph in the four languages, and the longer one, provided only in Croatian. The first paragraph offers a chronology, a linear, seemingly unproblematic development, in which the existence of the fish canning industry is just one phase in the development of this small coastal place and the wider region to which it belongs. The industry, known as "stinky" and unattractive and driving tourists away, was replaced by a hotel. This linear sequencing of history of Banjole suggests "the triumph" of a "clean", desirable industry of tourism over other modes of production and making a living in the local setting. It makes almost seven decades of the fish canning factory a temporal sequence that is seamlessly integrated into history. The "life" of this industry is marked by a clearly defined beginning and an end, and its pastness is absolute (Janowitz 1990: 1, as cited in Edensor 2005: 13) and thus incapable of making any intervention in the present (Feldman 2004: 165; Petrović 2014).

The second part of the inscription, however, challenges this image of a seamless time flow. Although also largely factual in character, this passage reveals an important aspect of the fish-canning industry: the fact that it offered a framework in which social life was organized and lived. Thus, the text clearly shows that the local impact of the fabrika went far beyond providing financial means to its employees. Particularly during the late socialist period, it provided a space and a means for education, leisure, health protection. This small monument to the local fish canning industry in Banjole thus reminds us that this industry cannot be described exclusively in terms of hard labor in bad and severe condi- 
tions, nor can its effects on the local environment be reduced to bad smell and dirty sea water. It also warns us that tourism and industry in the coastal area are not axiologically unambiguously opposed, but that their relation has been, for most of the 20th century modernity, ambiguous and full of tensions. ${ }^{3}$

In this article, I explore the various ways in which memories of labor in the fish-canning industry in the second part of the 20th century complicate and challenge prevalent views of the fish-canning industry as hard, "primitive", unwanted, "stinky", marginal, and strongly dispreferred in comparison with another source of income - tourism. The discussion is based on ethnographic interviews with former workers in the fish canning factories Plavica on the island of Cres, Kvarner on the islands of Lošinj, Susak and Unije, and Sirena on the island of Lastovo. ${ }^{4}$

\section{HARD LABOR}

Work in the fish canning factories was almost unanimously described by the former workers as hard and demanding, particularly for women, since this is one of the (rare) industries where hard labor was performed by female and not by male employees. In the fish canning factories on the northeast Adriatic coast, men usually performed maintenance tasks, worked as fishermen, and occupied leading positions (heads of production, factory managers). The women still remember this hard labor, and their memories are often somatic:

I still feel pain [points to her hands] when I think of it. (Anica, Lastovo)

We had hands in ice for whole days. When there was a lot of fish to process, we had to work from early mornings to 1 am or 2 am the next day. (Laura, Cres)

Eight hours in humidity, in steam - I am surprised that Ankica has not fallen ill. Women were in great danger of getting ill - they constantly had their hands in water. And then it was very hot and loud, particularly during the summer. (Nicolo, a boiler maintenance worker, speaking of his wife Anica, who worked in fish processing, Cres)

Conditions were very hard - water-fish-water-fish. We were cutting fish heads. Our hands got so hurt that they were bleeding. (Olga, Lošinj)

Cold water, cold fish... We had containers with burning coals next to our feet to warm us a bit. It is very hard for women in the fish industry. In winter, we would unload fish at the seafront and carry it to the factory. Your hands were constantly in the water. (Đanina, Cres)

\footnotetext{
${ }^{3}$ In her book Shaping the Shoreline: Fisheries and Tourism on the Monterey Coast Connie Y. Chiang writes on the similar relationship between industry and tourism (Chiang 2008). Also see Cronon 2008: xii.

${ }^{4}$ The interviews were conducted by the members of the Slovenian team of the bilateral project "Consequences of Deindustrialization of the Eastern Adriatic Coast: (Dis)Entangling People, Landscape and the Sea", Iva Kosmos, Martin Pogačar, and myself.
} 
We would go to the unloaded fish as deep as up to our waist. We were loading fish into wooden crates and carrying it outside. (Dinka, Cres)

It was terrible for me to go through the production unit, it was all in mud, in water, the women were wearing rubber boots... really terrible. (Mira, administration worker, Lošinj)

Nevertheless, this hard, repetitive labor was rarely a reason for the former workers in the fish canning factories to completely dismiss their working experience. On the contrary, most women we spoke to talked about their work in these factories with pride, even with nostalgia, which was also often somatically expressed, as in the case of Olga from Lošinj, who said at the end of our interview: "I would pack fish now as well," making the same repetitive moves with her hands as those she was used to while working in the factory. One of the reasons for this certainly lies in the fact that for a significant number of these women, their work also meant emancipation, freedom and being able to make decisions autonomously, and freedom from patriarchal control that was pretty tight in many parts of the former Yugoslavia in their youth. Dinka, who came to Cres from Bosnia and Herzegovina, said that working in the factory brought her freedom. "I was already fed up with asking for permission each time I wanted to go to the cinema, and I had also never seen the sea before."

I came from the countryside and was the ninth child in the family. When I was 12-13 years old, I had to wake up at 3 am or 4 am to go and look after sheep. So, working in the factory was not that hard for me. At least I was on my own, I had my salary. (Olga, Lošinj)

Work in the fish canning factory, although hard and performed in extremely poor conditions, simultaneously offered employees a means to build self-esteem and value as workers and community members. They talk with pride about their working abilities and readiness to work hard:

There was the production threshold we had to reach: we cut heads, put fish into salty water, and then fried them [shows everything with her hands]. (Dinka, Cres)

We would always exceed the threshold, all of us, we were young. We would clean more than four crates of fish in an hour. (Olga, Lošinj)

Similarly, the workers were proud of their products and emphasized their high quality: they stressed that "our factory had very good products"; "we were always congratulated for the good quality of our products" (Mira, Lošinj). In a context much larger than the fish-canning industry, these words point to the importance of the relationship between workers and the products of their labor. The centrality of the connection between the industrial worker and the products of industrial labor reflects the working-class culture tradition "that insisted on the ethic of the craft and, quite literally, on craftiness at the workplace, both vis-à-vis machines and the work process" (Muehlebach 2017: 122). A worker from Sesto, Italy, articulated

${ }^{5}$ The link between industrialization and women's emancipation in the context of socialist Yugoslavia was discussed by several authors, including Iva Kosmos (this issue); Borovičkić and Vene 2016; Jambrešić Kirin and Blagaić 2013; Modrić 2018; Vene and Borovičkić 2018; Bonfiglioli 2020. 
this importance as follows: "I experienced a passion for the work we performed. Because even as this work was extremely tiring, we felt that we were creating something" (ibid.: 123).

This relationship between the worker and the product of his work that significantly shaped the self-perception of workers in both Fordist and socialist industrial regimes is mostly extinct today, as we live in a time when, as John Berger stresses, factories became migratory just like workers (Berger and Mohr 2018: 7). Moreover, the nature of work changed dramatically: in our current condition, as Andrea Muehlebach points out, "we are beholden to machines like never before: 'those little computers' that we do not understand and that enslave us" (ibid.). ${ }^{6}$

\section{THE FACTORY AS A SOCIAL UNIVERSE}

Factory work is often seen as having debilitating consequences on the people performing it. Friedrich Engels wrote that "the miserable routine of endless drudgery and toil in which the same mechanical process is repeated over and over again is like the labor of Sisyphus. The burden of labor, like the rock, always keeps falling back on the worn-out laborer" (Engels, as cited in Benjamin 1999: 106). Workers' alienation has often been seen as a consequence of monotonous, hard labor (Matošević 2019: 91). Researching how workers subjectively experienced work, Blauner (1964; also see Korczynski 2014: 68) outlines dimensions of self-estrangement, powerlessness, meaninglessness, and social isolation. In his ethnographic exploration of the role of music among shop floor workers of the McTells company, Korczynski exposes it as an oppositional practice centrally related to workers' senses of alienation (Korczynski 2014: 91). In his words, "often, too often, time on the factory floor was experienced as alienated time - empty, meaningless, slow, and boring" (ibid.: 73).

Memories of workers in the fish canning industry during Yugoslav socialism provide a very different picture. For them, the repetitive, exhausting labor was not a reason to view their working experience in retrospect as alienating, pointless, damaging, or humiliating. One reason for different attitudes towards labor and its different valorization can already be found in Benjamin's insight that there is a class dimension of the perception of factory labor as boring and monotonous - such perception largely comes from the upper classes (Benjamin 1999: 106). Moreover, the monotonous, repetitive rhythm of cutting fish heads, packing fish into cans, packing cans into boxes etc. - was itself regulated by another rhythm - the one of music. Here, differently from what Korczynski suggests (2014), music is not opposed to, but in accordance with the rhythm of production. An important ingre-

\footnotetext{
${ }^{6}$ In his book Shop Class as Soulcraft: An Inquiry into the Value of Work, Mathew Crawford provides a detailed account of these changes in the relationship between the worker, the object/product of labor and the labor process and their profound consequences on how we understand and value labor (see Crawford 2009).
} 
dient of workers' social life in the fish canning factories and around them were music, singing and dancing. Songs seem to dominate the soundscape in the memories of labor in the fish canning factories:

When I came, I saw these women - frozen, they were singing. (Đanina, Cres)

It was nice back then, music, good company, we were singing constantly, there was also music over loudspeakers, there were songs that were modern then, like Kad si kupim mali motorin [When I buy myself a small motorcycle]. (Anica, Lastovo)

We sang a lot. Zdenka Dalmatinka was the one who sang most often:

Valfiorita [name of the Italian ship], prugo lošinjska

Ti si mi srića sva,

Vrati se, vrati se ženo, čekam te ja

or

Kad si dalečko u tuđem svijetu, u kraju dalekom

A ja mislim da si mi blizu jer si u srcu mom. ${ }^{8}$

(Kate, Lošinj)

For each 1st of May, the Army would organize a dance party, we were dancing quite often. (Anica, Lastovo)

And finally, the labor, however hard, was just one aspect of the factory life. Another, equally important aspect was socialization, through both informal and formal activities - spending time together, having fun during working hours, travelling to other factories, travelling for holidays. As Susan Woodward argued about Yugoslav socialism, "the employment status defined the identities, economic interests, social status and political loyalty of Yugoslav citizens. One's place of work was the center of one's social universe" (Woodward 2003: 76).

The workers of the fish canning factories fondly remember all these activities, and many photographs in their personal archives show this social aspect of the factory life.

We were making barbecue on the factory premises. We would not hide it, the manager knew and also ate with us. But the production never suffered because of it. I repeat, the production never suffered. (Nikola, Cres)

We went to a hotel in Gerovo for seven days - everything was paid for by the company. We were socializing all the time. We joined Following the revolution trails [Putevima revolucije] - everything was paid by the company again. (Anka, Cres)

Were really used to have fun and do all sorts of things. Always in good company. (Tončina, Lastovo)

We were going to Zadar, to the Ika factory to hold meetings, to attend Workers Councils. (Đanina, Cres)

\footnotetext{
7 Valfiorita, Lošinj trail / you are all my happiness / come back, come back, woman, I am waiting for you.

${ }^{8}$ When you are far away in a foreign land, in a far away place / And I feel you are close to me because you are in my heart.
} 


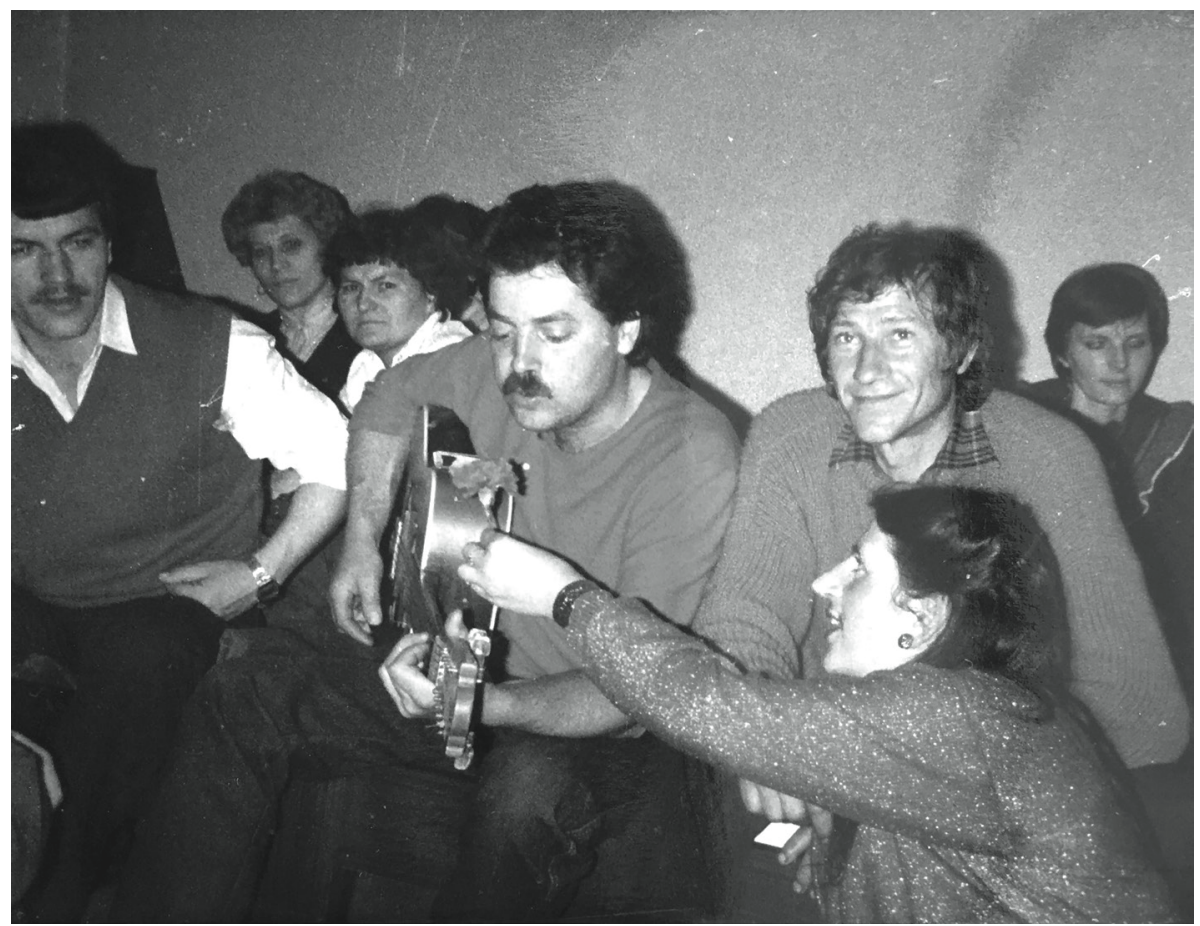

Photo 3. Workers of the Plavica factory in Cres. Personal archive of Anka and Nikola Koljevina

\section{IN THE RHYTHM OF THE FISH CANNING}

The factory was a site that generated community life that transcended its space and working hours: just like other socialist companies, it gave rhythm and form to community life in these small coastal and insular towns. Factories attracted a workforce from other parts of Yugoslavia (Bosnia, Slavonia, the Dalmatian hinterland) and significantly shaped the demography of these places - both in terms of immigration prompted by industrialization and depopulation as a consequence of deindustrialization (Jovanović et al. 2010). Cultural life and leisure were also shaped by the factory - either directly, or by workers maintaining ties established on the factory floor in their free time:

Companies used to organize dancing parties. The shipyard (škver) organized parties every first and last Saturday each month. It was held in the Kimen hotel, there were also awards... In summers, we would go out, to the cinema, to restaurants. We were complaining about life back then, but it was better than today. We would go out... if you felt like eating gnocchi, you would go to a restaurant and order gnocchi. (Anka, Cres)

The work of the fish canning factories was not isolated from the everyday life of the towns in which they were situated, but was closely intertwined with it. Daily life in these small Mediterranean towns was marked by the rhythm of factory work: sirens that would 
wake up the workers in early mornings, boats or buses taking workers to the factory or back from work, boats bringing fish to the seafront, and workers who would then take them to the factory... Repetition, crucial for the sense of rhythm (Elden 2004: ix), provided structure and logic to daily life in these towns.

Because no one in Selo had a clock, there was a siren every morning at 5 am. At 5.30 am the bus leaves, and at 6 am work begins, and lasts for eight hours. (Anica, Lastovo)

In the urban fabric of places like Cres, Lošinj, Hvar, or Lastovo, the factories were an important landmark as well as a reference. Perhaps the most illustrative example of this intertwinement of fish canning factories and towns is the one from Cres. The Plavica factory had a chimney that dominated the landscape of Cres. In the 1980s, the factory switched from coal to oil so the chimney was removed in 1987. The day the chimney was removed is still remembered by both the then workers of Plavica and other inhabitants of Cres. "We all cried that day", one of the workers recalled. It did not only change the familiar landscape of the town of Cres, but also disrupted some routines and habits. According to several people we talked to, when the chimney got removed, fishermen lost an important orientation point, as the smoke from it would tell them the direction of the wind.

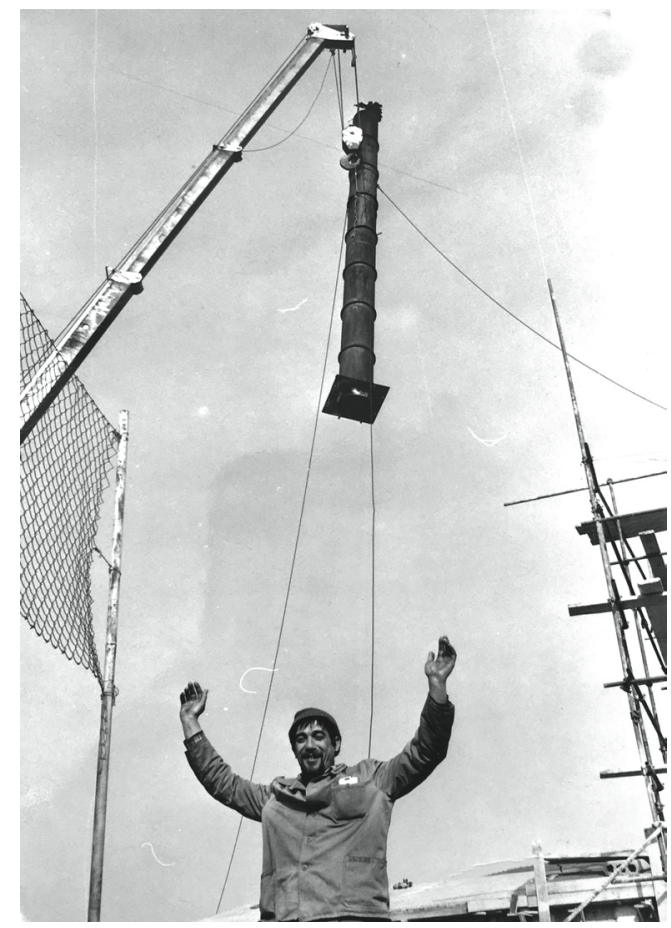




\section{THE ODOR}

The life of the fish canning factories was intertwined with the life of the towns, giving rhythm and a structuring logic to their everyday life. At the same time, however, the relationship between the two realms was never free of tension or an easy one. In the second part of the 20th century, intense industrialization was always contested in coastal towns and settlements as something that damages the landscape and the image of these places and compromises their tourism potential.

Henri Lefebvre, in his seminal work on rhythmanalysis where he attempts "to get us both to think space and time differently, and to think them together" (Elden 2004: ix), devotes considerable attention to the rhythm of Mediterranean towns. Together with Catherine Régulier, he writes about the crucial role that natural phenomena have in the rhythms of these towns. Unlike oceanic towns, which "are governed by the cosmic rhythms of tides lunar rhythms," Mediterranean towns "lie alongside the sea with (almost) no tides; so the cyclical time of the sun takes in a predominant importance there" (Lefebvre and Régulier 2004: 91). The annual cyclical time of the sun indeed has defined life and rhythm of the northeastern Adriatic towns for centuries. Two relatively recent phenomena, however, fixed this cyclical rhythm even more. The first is tourism, which Lefebvre and Régulies (2004: 97) describe as "a modern phenomenon that has become essential, and which in a curious way prolongs the historical problematic of conquests." For the inhabitants of Adriatic towns, the tourist season in contrast to winter months brings to mind a series of oppositions that define their lives: silence vs. sound, presence vs. absence, stillness vs. movement. Writing on Cres, Ivan Čolović says that the idealized imagination of the island outside of the tourist season as a realm of silence, peace and beauty belongs only to its occasional visitors and not to its inhabitants:

When the diversity of summer and its crowds withdraw, leaving boats pulled out from the sea, closed hotels, locked houses, when nights are long and the silence is interrupted only by wind and the sound of the city clock, total peace really takes over. But precisely because of its totality, this peace is unbearable. It poses a big problem and a challenge to the people on the island, and they deal with it using all means at their disposal. (Čolović [1973, 2018] 2019)

In his ethnographic and philosophical study on the city of Pula, Andrea Matošević describes the city as suffering from meteoropathy and stresses a difference in "the intensity of life, and in possibilities, depending on different seasons of the year" (Matošević 2019: 82). These differences produce a perception of time flow as cyclical rather than linear (ibid.). In regard to the rhythm of the city, in their narratives the inhabitants of Pula often juxtapose "the difference of diachronic and synchronic Pula, the city they remember and the city in which they live now" (ibid.: 74). In the past, the rhythm of city life was defined not solely by tourism, but also by the presence of the military and large industries that have been closed since (the Arena textile factory, the Uljanik shipyard). 
This brings us to another phenomenon crucial for the cyclical perception of time and rhythm of life: it is deindustrialization which leaves the life of coastal cities and towns defined by the dichotomy between the tourist season and the rest of the year, and their inhabitants totally dependent on it. It is important to note here, however, that the fish canning industry that shaped the rhythm of many of these towns in the 19th and 20th centuries was not in a mutually exclusive relationship with the natural, organic rhythm and approach to time that tourism seems to follow (Šuràn 2016: 117). These factories were themselves dependent on the natural cycles of presence vs. absence of fish in the sea. Guided by them, but also by the requirement not to interfere with the presence of tourists, they would stop production during the summer months.

In his study of rhythmanalysis, Henri Lefebvre points to a great importance of smells, emphasizing that "odours seem not to obey rhythms" (Lefebvre 2004: 41). ${ }^{9}$ The case of the fish canning factories confirms this observation, as the tension and incompatibility between the factories and towns (in spite of their intertwinement) is articulated through the narrative of the bad smell. The workers would "take" the factory with them after working hours by taking the smell of the fish to busses, town streets and cafes. This smell would distinctly and negatively mark them as "factory women" (tvorničarke):

When we would meet someone in town, they would say "Uh, these factory women!" We did not stink to ourselves. Once some of us were walking along the seafront, and a waiter in one of the cafes - he was still young, and we were young as well - he said: "How they stink after fish!" (Olga, Cres)

We had protective overalls, and everything, but the odor goes under your skin... (Đanina, Cres)

Sardines are among the worst fish - you could smell their odor kilometers away. You can wash yourselves as much as you want - it stays for two days. The entire bus smelled of fish. (Ivo, Lastovo)

The "Tvrdi" ship was transporting female workers from the harbor to the factory. I would rarely use it, because these women had such a strong odor. (Mira, Lošinj)

The female workers had their way of fighting insults and negotiating and stressing the social value that their labor brought to them:

I worked in the factory, and smelled of fish, but I was always careful to match the colors of my clothes. (Dinka, Cres)

When we used to go back from work, they would say that we stink of fish - but that was normal when you work. One smells of the environment in which one works. (Đanina, Cres)

My son once told me: "Mama, you smell like fish!" And I responded: "Maybe I stink, but my money does not!" (Anka, Cres)

${ }^{9}$ Smell and odor have important cultural, social and political implications. See, e.9., Corbin 1986; Classen et al. 1994; Henshaw 2014; Hurley 1997; Meisner Rosen 1997; Quercia et al. 2015. 
When these Bosnian women would get their salary - they would go to Rijeka, and get nice clothes. They were dressed like models! They would also go to the hairdressers. (Anka, Cres)

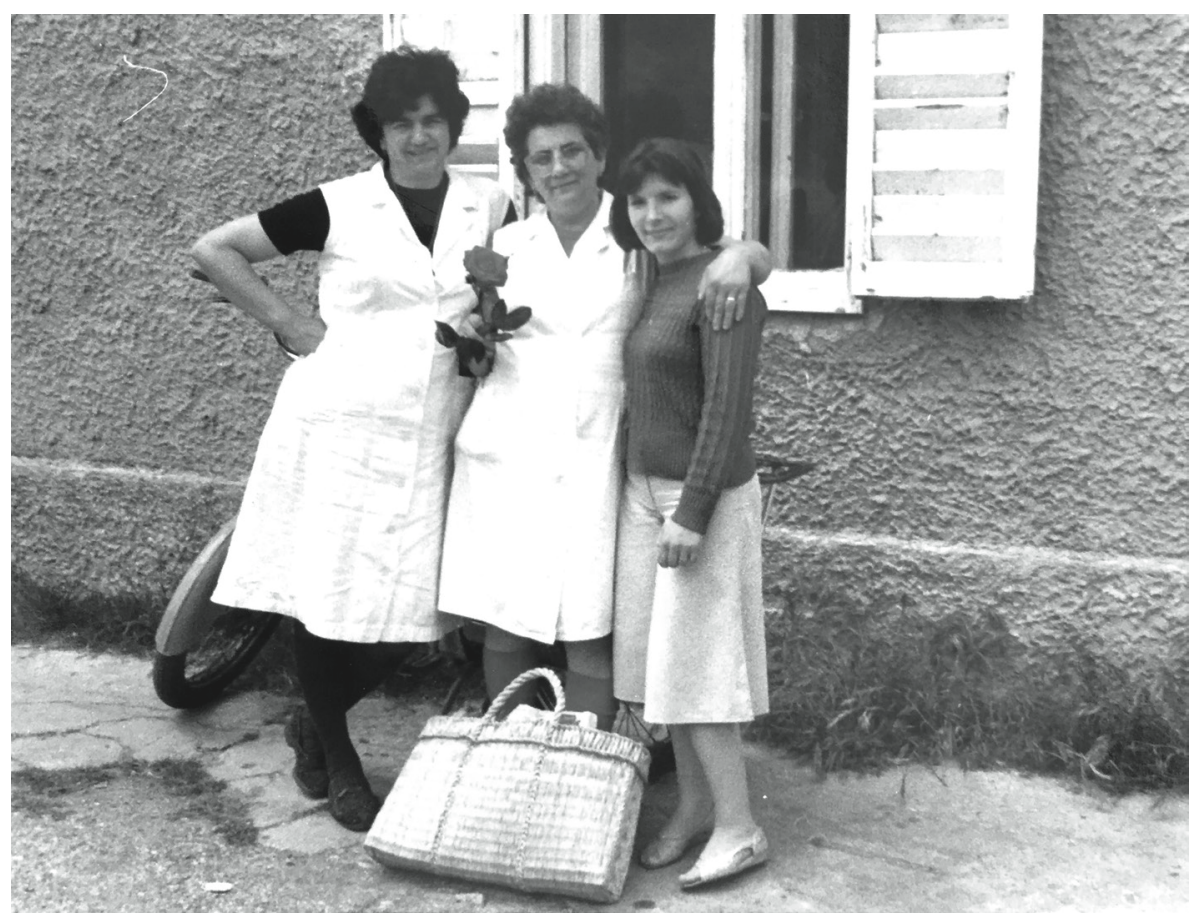

Photo 5. Workers of the Plavica factory in Cres. Personal archive of Anka and Nikola Koljevina

Bad smell was also the basic metaphor used to explain the decline of the fish canning industry by its former workers:

They intentionally closed the factory - and justified it with pollution and odor - they said, once tourism comes, we cannot have factories. (Dinka, Cres)

Why did they close the factory? Not because of economic reasons, but because it did not modernize. And because they wanted tourism. It stank and disturbed the development of tourism. (Mira, Lošinj)

Someone thought that fish stank. (Tonči, Lošinj)

[They were saying] Let us close it, it is disturbing, ships with fish are coming to the municipality building and unloading it there. Fish was unloaded, it stank. (Rosa, Lošinj)

Some did not like the fish odor... tourism, tourism. (Olga, Lošinj)

The bad smell is sharply opposed to tourism and actually contextualized as a social problem exclusively in relation to it. As Anica, a worker in the Sirena fish canning factory 
from the island of Lastovo told us, there "no one thought that fish stank, as there was no tourism back then."10 Such antagonistic relationship between the fish odor and tourism is not characteristic of only small coastal and insular towns in the northeastern Adriatic. It is a global leitmotif accompanying the decline of the fish canning industry that was closely intertwined with the local communities and important for their life. In her book on Monterey canneries, Connie Y. Chiang provides an insightful illustration of the fact that the elimination of odor as a consequence of the elimination of the fish canning industry and a "victory" of tourism would not necessarily bring improvement and progress to the local communities. In 1934, the company Del Monte Properties, which wanted to attract home buyers to the region, filed a lawsuit to the county court against sardine canning factories, claiming that

During sardine season, the prevailing winds blew from west to east, sending odors directly to the hotel Del Monte and its extensive grounds. The stench was often so strong that guests and employees became "nauseated and physically distressed." As a result, the company had lost patronage, and it expected the value of its said hotel and resort property [to] be highly depreciated. (Chiang 2008: 95-96)

Defending local canneries, lawyer John Milton Thompson emphasized several issues that strongly resonated with the situation in the Adriatic some decades later. He noted that "the odors were a 'mere matter of aesthetics affecting only the olfactory organs of super sensitive persons seeking pleasure at the pleasure resort conducted by the plaintiff.' Any odors created by the defendants," Thompson went on, "had caused "little, if any, financial loss to said Peninsula and little, if any, real discomfort or distress but rather a financial annoyance to ... persons having no true relation to the public welfare of the said community" (ibid.: 96).

\section{WHY IS THERE NO MUSEUM OF THE FISH CANNING INDUSTRY?}

Workers understand and explain the closing of the fish canning factories in a broader context of deindustrialization, privatization and a decline of industry as we knew it in the 20th century. This industry is disappearing together with the whole world that was created and maintained by it. Most often, workers are the only ones who keep memories of the decades of operation of these factories. Public memorializations of labor history of fish canning are rare. These rare memorializations are, as a rule, a result of efforts by individuals, local institutions and communities." As in the case of the can-shaped monument to

\footnotetext{
${ }^{10}$ In socialist Yugoslavia, the island of Lastovo was a military base of the Yugoslav army and movement of civilians was restricted. It became a tourist destination only in the recent decades.

${ }^{11}$ For instance, in the town of Cres, there is a cafe bar Plavica in the former fish canning factory building with the same name; in 2018, the Stari Grad museum in Hvar organized the exhibition "From baraka to fabrika: Fish processing on the island of Hvar"; in 2015, a collection on fish canning in Isola was established by Srečko Gombač in the Parenzana museum. However, the museum was closed in November 2016. The
} 
the fabrika in Banjole, where the commemorative text in Croatian is more elaborated - and emotionally laden - than those in Italian, English, and German, public memorializations of the fish canning industry are more oriented toward the local community than to outside audiences or tourists. Nowadays tourism is the dominant, if not the only, economic activity on the northeastern coast of the Adriatic. Because of this, a lack of effort to include the history and heritage of fish processing into the tourism offer comes as a surprise. Contrary to places around the globe such as Lisbon in Portugal, Stavanger in Norway, and Monterey in California, US, there is a lack of interest of promoting and commodifying fish canning in terms of cultural heritage in Izola, Lošinj, Cres, Hvar, Lastovo and other places where fish canning factories existed in the 19th and the 20th century.

Reasons for this absence of interest and effort are complex and manifold. At least to some extent, they are connected with the difficulties faced by any attempt to regard history and remnants of the socialist industry as cultural heritage. ${ }^{12}$ Moreover, the process of deindustrialization, although long-lasting, is by no means completed. Some of the major steps in this process are happening right now. We are witnessing a dramatic and heartwrenching struggle of the workers of Uljanik and 3rd May shipyards in Rijeka and Pula.13 The inhabitants of these cities join their struggle to preserve the industry that has provided many of them for life, but also significantly defined the urban character of these two cities, largest in the northeastern Adriatic. The conclusion of this difficult process, marked not only by the struggle for survival, meaning and the value of labor and the workingclass culture, but also for the valuable plots of land at the coast, is often presented as an inevitable step from industry towards tourism. However, the fact that this process is still unfinished, as well as its problematic and often tragic effects, make commodification of the history of industrial labor difficult, if not impossible, as commodification of an industry can only come as a confirmation of the definiteness and irreversibility of deindustrialization. Dominant politics and narratives claim that the replacement of industry with tourism (and other tertiary sector activities) is a necessary, inevitable and desirable developmental step. The memories of labor in the fish canning industry however caution us that such claims should not be taken for granted. These memories, although rarely present in public spaces, are capable of bringing back the whole world of work and the vanished rhythm of life of coastal towns. In line with Lefebvre's statement that "at no moment has the analysis of rhythms and the rhythmanalytical project lost sight of the body" (Lefebvre 2004: 67), recalling the rhythms of these towns from the time when fish canning factories were operational to a large extent goes through the body. The world shaped by the fish canning industry unfolds in deeply embodied, sensorial memories. In visual memories of the boat and the bus bringing workers to the factory; of the fishing boat unloading fish at

organization Siva zona (Grey Zone) in Korčula is running the project "Industrial Heritage of the Island of Korčula," which, among other things, studies the heritage of fish processing on the island of Korčula.

12 I wrote on these difficulties in detail in Petrović 2012, 2013, 2014.

13 Dragan Grozdanić's article “Uljanikova jesen” (Uljanik's fall) features several dramatic and personal stories of (former) Uljanik workers and their struggle to secure a living for their families (Grozdanić 2009). 
the seafront; of the factory chimney dominating the landscape and orienting fishermen at sea; in olfactory memories of the fish odor, an unpleasant one, but also a pleasant smell of frequent barbecues, new clothes and perfumes women could afford thanks to their hard work; in aural memories of songs sung during working hours, or of music coming from the factory loudspeakers; of music listened and danced to at parties organized weekly in a nearby hotel. In gestures and moves that the former factory workers still unconsciously make when talking about their work: cutting fish heads, cleaning fish, packing it in cans, wrapping cans in neatly labeled paper wraps sending them to the big world from small places on the Adriatic Sea. ${ }^{14}$

\section{REFERENCES AND SOURCES}

Benjamin, Walter. 1999. The Arcades Projects. Cambridge MA, London: The Belknap Press of Harvard University Press.

Berger, John and Jean Mohr. 2018. Sedmi čovek. Knjiga u slikama i relima o iskustvu stranih radnika u Evropi. Beograd: Fabrika knjiga.

Blauner, Robert. 1964. Alienation and Freedom. Chicago: University of Chicago Press.

Bonfiglioli, Chiara. 2020. Women and the Industry in the Balkans. The Rise and Fall of the Yugoslav Textile Sector. London, etc.: I. B. Taurus. https://doi.org/10.5040/9781838600778

Borovičkić, Marija and Lea Vene. 2016. “'Višak sjećanja' industrijske baštine Vele Luke”. Lanterna 1: 74-81.

Chiang, Connie Y. 2008. Shaping the Shoreline. Fisheries and Tourism on the Monterey Coast. Seattle, London: University of Washington Press.

Classen, Constance, David Howes and Anthony Synnott. 1994. Aroma.The Cultural History of Smell. New York: Routledge.

Corbin, Alain. 1986. The Foul and the Fragrant. Odor and the French Social Imagination. Cambridge: Harvard University Press.

Crawford, Mathew B. 2009. Shop Class as Soulcraft. An Inquiry into the Value of Work. London: Penguin Books.

Cronon, William. 2008. "Foreword. On the Shore between Work and Play". In Connie Y. Chiang. Shaping the Shoreline. Fisheries and Tourism on the Monterey Coast. Seattle, London: University of Washington Press.

Čolović, Ivan. [1973, 2018] 2019. "Axis mundi na Cresu". Novosti, 13 November. Available at: https:// www.portalnovosti.com/axis-mundi-na-cresu (originally published in the Duga weekly, 15 Novem-

${ }^{14}$ The paper packaging used in the Kvarner factory in Lošinj (closed in 1974) that we rescued from the ruined factory building reveals several aspects of the Yugoslav fish canning industry of the time that complicate the usual assumptions concerning the production of goods in the socialist economy as lowquality and directed towards the domestic, state-controlled market, and of fish canning industry as local and bound to the local market due to a low quality of the products and primitive production. These wraps reveal that Kvarner's product were very diverse - not only sardines, but also mackerel, anchovies, squid, tuna, and that they were canned in a variety of ways (in olive oil, seed oil, with lemon or vegetables). Several languages - English, Italian, French, German - suggest that most cans produced by Kvarner were sold beyond the borders of Yugoslavia. 
ber 1973, reprinted with slight changes in Ivan Čolović, Slike i prilike. Redom kojim su se ukazivale. Belgrade: XX vek, 2018).

Grozdanić, Dragan. 2019. “Uljanikova jesen”. Novosti, 27 April. Available at: https://www.portalnovosti. com/uljanikova-jesen.

Hurley, Andrew. 1997. "Busby's Stink Boat and the Regulation of Nuisance Trades, 1865-1918". In Common Fields. An Environmental History of St. Louis. Andrew Hurley, ed. St. Louis: Missouri Historical Society Press, 145-162.

Edensor, Tim. 2005. Industrial Ruins. Spaces, Aesthetics and Materiality. Oxford, New York: Berg. https://doi.org/10.5040/9781474214940

Elden, Stuart. 2004. "Rhythmanalysis. An Introduction”. In Henri Lefebvre. Rhythmanalysis. Space, Time and Everyday Life. London, New York: Continuum, vii-xvi.

Feldman, Allen. 2004. "Memory Theaters, Virtual Witnessing, and the Trauma-Aesthetic". Biography 27/1: 163-202. https://doi.org/10.1353/bio.2004.0030

Henshaw, Victoria. 2014. Urban Smellscapes. Understanding and Designing City Smell Environments. New York, London: Routledge. https://doi.org/10.4324/9780203072776

Jambrešić Kirin, Renata and Marina Blagaić. 2013. "The Ambivalence of Socialist Working Women's Heritage. A Case Study of the Jugoplastika Factory”. Narodna umjetnost 50/1: 40-73. https://doi. org/10.15176/VOL5ONO102

Janowitz, Anne. 1990. England's Ruins. Poetic Purpose and the National Landscape. Oxford: Blackwell.

Jovanović, Jelena, Jelica Galić and Peter Mackelworth. 2010. “Odraz gašenja otočnih pogona za preradu ribe na depopulaciju hrvatskih otoka". Naše more 57/3-4: 153-163.

Korczynski, Marek. 2014. Songs of the Factory. Pop Music, Culture, and Resistance. Ithaca, London: ILR, Cornell University Press. https://doi.org/10.7591/cornell/9780801451546.001.0001

Lefebvre, Henri. 2004. Rhythmanalysis. Space, Time and Everyday Life. London, New York: Continuum.

Lefebvre, Henri and Catherine Régulier 2004. "Attempt and the Rhythmanalysis of Mediterranean Cities". In Henri Lefebvre, Rhythmanalysis. Space, Time and Everyday Life. London, New York: Continuum, 87-100.

Matošević, Andrea. 2019. Doći u Pulu, dospjeti u tapiju. Etno-filozofska studija lokalnog fenomena. Zagreb: Durieux, Institut za etnologiju i folkloristiku.

Meisner Rosen, Christine. 1997. "Noisome, Noxious, and Offensive Vapors, Fumes and Stenches in American Towns and Cities, 1840-1865". Historical Geography 25: 49-82.

Modrić, Dragana. 2018. "Kako (je) tvornica mijenja(la) grad. Primjer tvornice Dalmatinka”. Narodna umjetnost 55/2: 129-146. https://doi.org/10.15176/vol55no206

Muehlebach, Andrea. 2017. "The Body of Solidarity. Heritage, Memory, and Materiality in Post-Industrial Italy". Comparative Studies in Society and History 59/1: 96-126. https://doi.org/10.1017/ S0010417516000542

Petrović, Tanja. 2012. Yuropa. Jugoslovensko nasleđe i politike budućnosti u post-jugoslovenskim društvima. Beograd: Fabrika knjiga.

Petrović, Tanja. 2013. "Museums and Workers. Negotiating Industrial Heritage in the Former Yugoslavia”. Narodna umjetnost 50/1: 96-119. https://doi.org/10.15176/VOL50NO104

Petrović, Tanja. 2014. "Mourning the Lost Modernity. Industrial Labor, Europe, and (Post)Yugoslav PostSocialism". In Mirroring Europe. Ideas of Europe and Europeanization in Balkan Societies. Tanja Petrović, ur. Leiden, Boston: Brill, 91-113. https://doi.org/10.1163/9789004275089_006

Quercia, Daniele, Rossano Schifanella, Luca Maria Aiello and Kate McLean. 2015. "Smelly Maps. The Digital Life of Urban Smellscapes”. arXiv.org. Ithaca: Cornell University Press. Available at: https:// arxiv.org/abs/1505.06851. 
Šuràn, Fluvio. 2016. Turizam i teritorij. Uvod v antropologiju turizma. Pula: Sveučilište Jurja Dobrile u Puli.

Vene, Lea and Marija Borovičkić. 2018. "Intangible Industrial Heritage of Vela Luka”. Studia Ethnologica Croatica 30: 295-320. https://doi.org/10.17234/SEC.30.10

Woodward, Susan. 2003. "The Political Economy of Ethno-Nationalism in Yugoslavia”. Socialist Register 39: 73-92.

\section{INDUSTRIJA KONZERVIRANJA RIBE I RITAM DRUŠTVENOG ŽIVOTA NA SJEVEROISTOČNOJ OBALI JADRANA}

Prilog osvjetljava društveni svijet koji se oblikovao oko tvornica za konzerviranje ribe u malim obalnim i otočkim naseljima na sjeveroističnom Jadranu. lako se povezuje $s$ teškim, neugodnim radom i izuzetno zahtjevnim uvjetima rada, industrija prerade ribe, naročito u periodu poznog socijalizma, nudila je okvir u kojemu je organiziran smisleni društveni život ne samo radnica i radnika nego i čitavih lokalnih zajednica. Zato je značaj lokalnih tvornica za preradu ribe bitno nadilazio osiguravanje sredstava za život zaposlenih i njihovih obitelji. U prilogu se društvena značenja prerade ribe na jugoslavenskom Jadranu osvjetljavaju kroz prizmu odnosa između te industrije, koja je u velikoj mjeri nestala, i turizma, koji postaje dominantan (i često jedini) izvor prihoda za lokalne zajednice. Koncept ritmoanalize Henryja Lefebvrea pokazao se produktivnim za promatranje kompleksnih i često dvosmislenih odnosa između dviju industrija kao i za pripovijedanje povijesti konzerviranja ribe kroz slike, zvukove, mirise, osjećaje. Ova intenzivna utjelovljena, senzorna sjećanja na rad u tvornicama ribljih konzervi problematiziraju i destabiliziraju dominantne interpretacije zamjene industrije turizmom (i drugim tercijarnim aktivnostima) kao neophodnog, neizbježnog i poželjnog razvojnog koraka.

Ključne riječi: konzerviranje ribe, rad, ritam društvenog života, smrad, industrijska baština 